\title{
THE EUROPEAN SOCIAL CHARTER: AN END TO THATCHERISM?
}

\author{
Keith Ewing
}

\section{INTRODUCTORY}

The purpose of this article is to consider the controversial European Social Charter, and in particular to consider whether it marks an end to Thatcherism in Britain. The Social Charter was concluded by member states of the European Communities, the institutions of which have the power to legislate on economic and social questions. The Charter may be of more than passing interest for Canadians, highlighting a missed opportunity in the negotiations for the free trade agreement with the United States, an agreement which is functionally equivalent to the E.C.

\section{THE EUROPEAN SOCIAL CHARTER}

The European Social Charter is a solemn declaration adopted by 11 of the 12 member states at a summit in Strasbourg on 10 December 1989 . The only government not to sign was the British, by whom the document was dubbed a "European Socialist Charter", running counter to the free market philosophy which had informed domestic labour law policy since 1979. The aims of the Charter were first to remove regional imbalances in social matters in order to ensure fair economic competition between enterprises in different member states, but secondly to promote social consensus by ensuring that workers as well as corporations benefit from the creation of the "single market" in 1992. The proposal, then, is to raise the level of social protection throughout Europe.

In order to achieve these goals, the Charter addresses a member of items in a comprehensive package of some 30 articles. These deal with freedom of movement of workers (articles 1-3); the right to a fair and equitable wage, defined to ensure that workers have a decent standard of living (article 5); the improvement of living and working conditions (with reference particularly to the needs of atypical workers who are often denied social protection) (articles 7-9); the right to adequate social protection and an adequate level of social security benefits (article 10); the right to freedom of association and collective bargaining, including the right to strike (article 11); the right to equal treatment for men and women (article 16); and procedures for worker participation in decisionmaking, particularly in the cases of technological change and business restructuring (articles $17 \&$ 18).

It has to be said, however, that the European Social Charter has no legal status. As others have pointed out, it is not a treaty under international law, nor is it part of community law. It can only become effective if its terms are formally implemented by the community legal institutions. This means that provisions of the Charter must be adopted by the Commission and approved by the Council of Ministers after consultation with the European Parliament, following which they may be implemented as regulations or (more usually) directives which would be binding in Member States under Community Law. But having said this, under the direction of the Greek commissioner, Ms. Papandreou, aggressive steps have been taken to implement the Charter. Its publication was soon followed by an Action Programme by the
Commission, in which no fewer than 47 different initiatives were proposed, many of these having led in turn to the publication of draft directives. These cover a wide range of issues, and if introduced will lead eventually to a radical change in the shape of British labour law.

\section{THATCHERISM IN BRITAIN}

There is a great deal of misunderstanding about the nature of Thatcherism. It is, however, not a unique or distinctive political theory or philosophy. Rather, it is simply a commitment to a particular form of economic liberalism which places faith in the functioning of the free market and the removal of regulatory legislation from economic and social affairs. As such it has an honourable intellectual pedigree which can be tracked back to Adam. Smith and which finds contemporary expressiun in the works of Friedman and Hayek, and less convincingly, yet more despairingly, in the U.S. law reviews. But just as Thatcherism is not a novel economic theory, equally it is not the first time such policies have been pursued by governments in Britain. A similar approach to economic policy was adopted in the inter-war period when the state withdrew from economic management and allowed market forces to prevail, with devastating consequences for unions and their members. The effect of post-war Keynesian policies adopted by governments of both parties until at least the early 1970s has tended to dull our memories about historical trends.

So far as contemporary labour law is concerned, the effect of Thatcherism has been to deregulate employment standards legislation and deconstruct collective labour law. Both varieties of labour law were viewed as distorting the proper functioning of the free labour market, leading in turn to a lack of competitiveness and to unemployment. Under Thatcherism, then, labour law assumes a radically different role than that which it had performed in the past. Rather than being regarded as a means for protecting workers from the naked abuse of employer power, such legislation is removed and workers are left with whatever protection the common law and the market-place can provide. And rather than being viewed as a means of allowing workers to participate through their trade union in making and administering the rules which govern the working life, both trade unionism and collective bargaining are denied any legitimacy in a regime which worships the free market above all else.

The deregulation of employment standards has not led to a complete removal of such legislation but, equally, government initiatives have been far-reaching. Legislation introduced since 1980 has seriously undermined the British minimum wage fixing laws and has also withdrawn the statutory protection from unjust discharge for many workers. The deconstruction of collective labour law has on the other hand removed some of the state props for free collective bargaining. There is now in Britain no procedure equivalent to the Canadian certification procedure, where an employer can be required to bargain with a union enjoying high levels of support in the workplace. Most forms of 
trade union security are unlawful. It is unlawful for an employer to refuse to hire someone because he or she is not a trade union member and it is unlawful to take action short of dismissal and unfair to dismiss someone on the ground of non-union membership. Finally, the freedom to strike has been seriously curtailed by the introduction of measures which make it easier for an employer to obtain injunctive relief and damages against trade unions on the one hand, and to dismiss striking workers on the other.

\section{THE SOCIAL CHARTER AND THATCHERISM}

At first sight there thus appears to be a conflict between Thatcherism and the Social Charter. In contrast to the free market thinking informing labour law under Thatcher, the Charter is inspired by a vision of a social market which will require regulation and reconstruction on a large scale. As a result, the British labour movement is greatly optimistic about the Charter, and the labour party is committed to signing it as soon as it comes into office. But at a risk of sounding cynical, that optimism may be misplaced. For even though community law is a form of higher law, and even though Thatcherism is in decline (with her successor apparently more committed to European integration), there may still be a need for some caution about the future and several reasons for thinking that the ideology which informed Thatcherism will not be easily replaced. Not least among the problems in this direction is the text of the Charter itself. Although it refused to sign, the British government did successfully negotiate the inclusion in article 11 of a right of workers not to join a trade union (thereby prohibiting the union shop on a European wide basis), as well as an exclusion of civil servants from the protection for the right to join trade unions, (thereby avoiding any further embarrassment over its decision to withdraw union rights from 5,000 or so civilian staff employed at General Communications Headquarters [a listening station]).

But there are perhaps more serious difficulties associated with the Social Charter. One of these related to the legislative process in community law. As already pointed out, the Social Charter is not a self-executing document and its different provisions need to be introduced into community law in the shape of directives or regulations. Under the Treaty of Rome, however, legislative proposals "relating to the rights and interests of employed persons" need the unanimous approval of all 12 member states. As a result, the British government, not having signed the Charter, has the power to veto any of the important initiatives which are taken to implement its terms. It is true that there are a number of other treaty provisions which allow for majority approval only and that some labour law directives could be introduced under these provisions. But it is clear that the most important measures will require unanimous support and that those which do not can be frustrated by grudging implementation by national governments. Once made, a directive is not usually self-executing but will need implementing legislation in each member state before it will be legally enforceable there. Conservative governments have already frustrated earlier social policy initiatives - such as pay equity by cumbersome procedures for enforcing the law and the creation of wide defences for employers to justify not complying with its terms.
The process of introducing and implementing the terms of the Charter is thus likely to be long and tortuous. But even if these problems are overcome, the full delivery of the Commission's Action Programme could prove to be a source of some disappointment. It is true that the Action Programme proposes a large number of initiatives and that many important draft directives have already been introduced. These include measures on the contract of employment; the organization of working time; and maternity provision for pregnant women. But while important, the measures are nevertheless peripheral to the main problems which are and which have been affecting British unions in the last decade. Perhaps the critical concern of the organized labour movement is with the collective bargaining and right to strike provisions contained in articles 11,12 , and 13 of the Charter. It is here that the unions in Britain are most vulnerable, but it is here that the Action Programme has almost nothing to say and certainly nothing concrete to offer in terms of proposed legislative instruments. Indeed, it is arguable that the pressure in the E.C. for the introduction of a works council system on the German model (with a proposed directive on a European Works Council) will further undermine trade union organization. By requiring joint consultation procedures in all European-Wide enterprises, this may make it even more difficult in practice for traditional trade unionism to become established. Employers would be well advised to seize the opportunity to set up such procedures to further dull support or enthusiasm for collective bargaining by independent trade unions.

\section{CONCLUSION}

The European Social Charter thus challenges the free market philosophy which has inspired labour law under the Conservative government. But although Mrs. Thatcher has been replaced by the less strident Mr. Major, there has been no softening of the hard line on labour law reform. It is thus optimistic to think that Thatcherism will wither on the vine. This is not to deny the importance of the Social Charter which is a bold and imaginative document. Nor is it to deny that the Charter may lead to some changes to British labour law, and some very significant ones at that. But there is a need for a realistic assessment of what the Charter is likely to achieve. It is clear that if the Social Charter is to make any positive contribution to the lives of working people, hard political battles will have to be fought both in Europe and at Westminster if its terms are to become a reality. The first battle is to secure the election of a Labour government which is committed to signing the Charter. But that will only be the beginning of what proves to be a long and arduous campaign. A very real concern is that, in some ways, the Charter is a potential source of trade union weakness as it is strength. It signals the end of trade union security arrangements and it adds to the pressure which has been welling up in Europe since the mid 1970s for the extension of some kind of works council system which will take British unions at least into new and potentially dangerous terrain.

K.D. EWING, University of London, King's College, Professor of Public Law. (This is an abbreviated version of a paper delivered to a seminar at the Faculty of Law, University of Alberta, on 19 April, 1991.) 